\title{
Non RhD isoimmunization causing severe hemolytic disease of fetus and newborn in Rh positive pregnancies: report of 2 cases with review of literature
}

\author{
Geetika Sharma, Sangeeta Pahuja*, Deeksha Singh, Ramvilash, Manisha
}

\begin{abstract}
Department of Immunohematology and Blood Transfusion, Lady Hardinge Medical College and Associated Hospitals, New Delhi, India
\end{abstract}

Received: 19 January 2020

Revised: 23 February 2020

Accepted: 27 February 2020

\author{
*Correspondence: \\ Dr. Sangeeta Pahuja, \\ E-mail: sangeeta.sindhwani@gmail.com
}

Copyright: (C) the author(s), publisher and licensee Medip Academy. This is an open-access article distributed under the terms of the Creative Commons Attribution Non-Commercial License, which permits unrestricted non-commercial use, distribution, and reproduction in any medium, provided the original work is properly cited.

\begin{abstract}
Anti D immunoprophylaxis widespread use in antenatal patients has led to dramatic reduction in the rates of alloimmunization due to anti $\mathrm{D}$, which is the most common $\mathrm{Rh}$ antibody causing severe Hemolytic Disease of Fetus and New born (HDFN). However, there has been increase in the rates of non $\mathrm{Rh} D$ antibodies causing alloimmunization in pregnant women and leading to moderate to severe HDFN. We hereby report two cases of neonates presenting with moderate to severe HDFN with strongly positive DAT due to Rh anti-c antibody in Rhpositive mothers. Thus, antenatal antibody screening should be done in all Rh-positive pregnant women to prevent the diagnostic delay of HDFN occurring due to Non anti-D isoimmunization in the fetus.
\end{abstract}

Keywords: Anti-c antibody, Hemolytic disease, Hyperbilirubinemia, Isoimmunization

\section{INTRODUCTION}

Hemolytic Disease of Fetus and Newborn (HDFN) is the destruction of fetal and newborn red cells by maternal red cell alloantibodies that are specific for inherited paternal red cell alloantigen(s). A French midwife in a set of twins first reported it in 1609. In 1941, Levine and colleagues suggested that destruction of red cells (RBCs) in the fetus and newborn may be due to maternal alloimmunization against blood group antigens of the unborn child. ${ }^{1,2}$

HDFN is one of the major causes of perinatal morbidity and mortality in India. The antibodies most commonly associated with severe HDFN are anti-D, anti-c and anti$\mathrm{K}$ (KEL1). ${ }^{3}$ Anti D immunoprophylaxis has led to dramatic reduction in the rates of alloimmunization due to anti D from $14 \%$ to $1-2 \%$ in west, which was further reduced significantly by antenatal immunoprophylaxis to $0.1 \% .^{4}$
Apart from immunoprophylaxis, more widespread antenatal antibody screening has contributed to the decline in rate of morbidity and mortality by anti D alloimmunization. Other factors like advancements in fetal assessment by Doppler (Middle Cerebral Artery Peak Systolic Velocity), ultrasonography, cordocentesis, allele-specific gene amplification studies on fetal cells in amniotic fluid, fetal DNA analysis in maternal plasma have significantly contributed in decreased fetal mortality. In India, though anti $\mathrm{D}$ is still the most common antibody responsible for alloimmunization, but the advancements in the screening techniques have changed dramatically the spectrum of antibodies causing alloimmunization in antenatal women over the last few decades.

There is increase in the rates of non $\mathrm{Rh} \mathrm{D}$ antibodies causing alloimmunization in pregnant women and leading to moderate to severe HDFN. 


\section{CASE REPORT}

We hereby report 2 cases of non $\mathrm{Rh}(\mathrm{D})$ isoimmunization in neonates from our tertiary care hospital presenting with HDFN.

\section{Case 1}

A term female infant, appropriate for gestational age with birth weight of $3 \mathrm{Kg}$ presented in the emergency of Kalawati Saran Children's hospital on day 5 of life with complaints of lethargy, decreased oral intake, yellowish discoloration of sclera and skin (involving the palms and soles). It was progressively increasing since $2^{\text {nd }}$ day of life. The baby was delivered by caesarean section in outside hospital and it was an unbooked and unimmunized pregnancy, G2 P2 L0A1 with history of intrauterine death of first female child at term. The general condition of the patient was poor. Baby presented with tachycardia (HR- 138/min) and Tachypnea (RR$62 / \mathrm{min}$ ). On physical examination, icterus was present along with mild pallor. However, no hepatosplenomegaly was evident. No history of blood transfusion during previous/ present pregnancy was elicited.

Hematological findings of the baby revealed mild anemia $\mathrm{Hb}-12.5 \mathrm{~g} / \mathrm{dL}$, RBC count- $3.07 \times 10^{6} / \mu \mathrm{L}$ and raised reticulocyte count $(15 \%)$. Biochemical investigation showed markedly raised indirect bilirubin (Total bilirubin- $40.2 \mathrm{mg} / \mathrm{dL}$, indirect bilirubin- $21.0 \mathrm{mg} / \mathrm{dL}$ ). Clinically, neonatal sepsis was considered, and double surface phototherapy was started. However, as the child did not show improvement, meanwhile double volume exchange transfusion was planned and requisition for the same was received in the Department of Immunohematology and Blood Transfusion in our hospital.

\section{Case 2}

A term female infant presented on day 6 of life in the emergency of Kalawati Saran Children's hospital with complaints of yellowish discoloration of the sclera and lethargy. The baby was delivered in an outside hospital and it was an unbooked and unimmunized pregnancy, G2 P2 L1A0 with no bad obstetric history.

On physical examination, icterus and severe pallor was present. (Hb-3 g/dL, hematocrit-9) with raised reticulocyte count (corrected R/C-5\%). Biochemical investigation showed indirect hyperbilirubinemia (Total bilirubin- $12 \mathrm{mg} / \mathrm{dL}$, indirect bilirubin- $9 \mathrm{mg} / \mathrm{dL}$ ). Top up transfusion was planned for the baby in view of severe anemia and requisition for the same was received in the Department of Immunohematology and Blood Transfusion in our hospital.

In case 1, mother's and baby blood group were ' $\mathrm{O}$ ' $\mathrm{Rh}$ positive (Figure 1). Father's sample was not available. Antibody screening 3 - cell panel (ID- Diacell 1-11-111 asia, Biorad) of the mother sample was positive. Further, antibody identification 11-cell panel (ID-Diapanel) revealed presence of anti c alloantibody by ruling out other clinically significant antibodies.

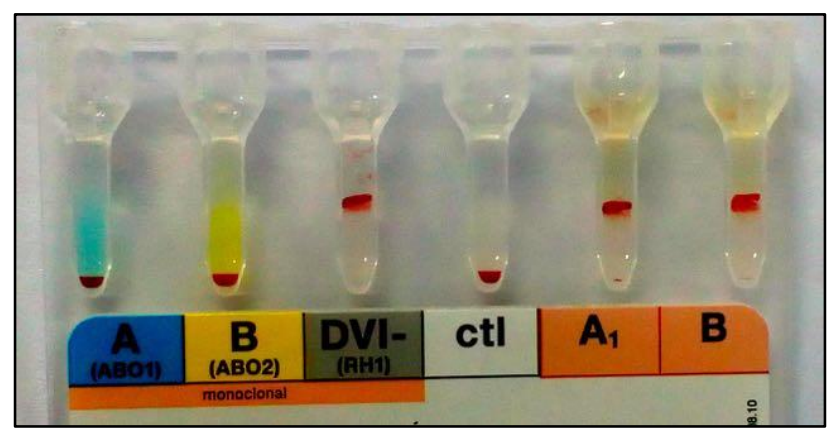

Figure 1: Blood group of the baby was confirmed as $O$ $\mathrm{Rh}$ positive by forward and reverse blood grouping at $37^{\circ} \mathrm{C}$ (Case 1).

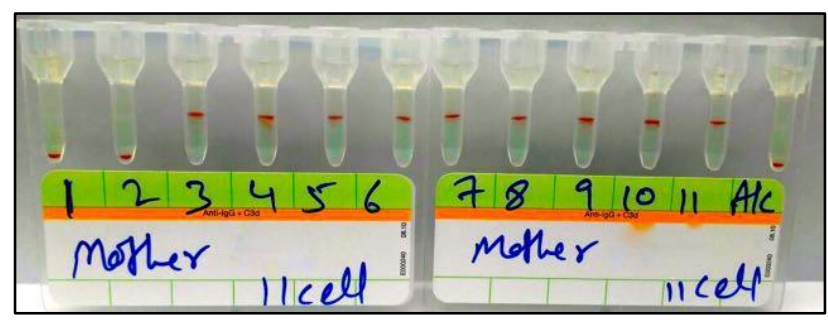

Figure 2: Antibody identification 11- cell panel (IDDiapanel, Biorad) in Liss Coomb's phase at $37^{\circ} \mathrm{C}$ of mother sample was suggestive of Anti $\mathrm{c}$ antibody with negative autocontrol in (Case 1).

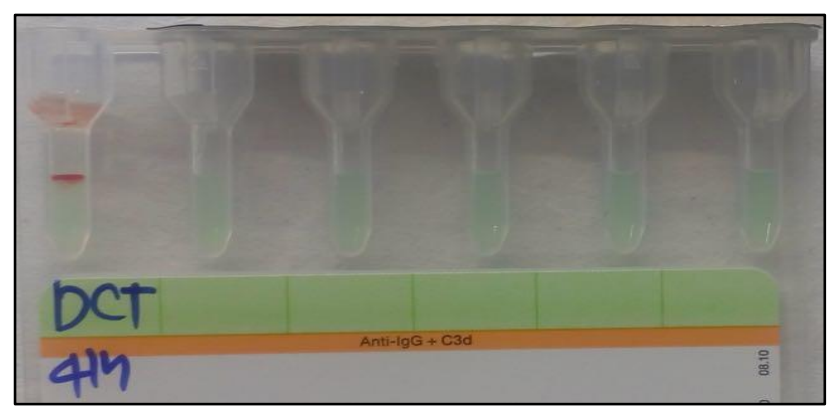

Figure 3: Direct coomb's test of the baby was strongly positive (4+) (Case 1).

(Figure 2) Select cells were used to rule out underlying anti E. Baby Direct coomb's test was strongly positive (4+) and further DCT profile showed presence of IgG. (Figure 3 and 4) Rh- kell antigen phenotyping revealed that the mother was ' $c$ 'antigen negative and baby was ' $c$ ' antigen positive (Figure 5). In case 2, mother's blood group was B Rh positive, father's blood group was also B $\mathrm{Rh}$ positive and baby's blood group was ' $\mathrm{O}$ ' Rh positive . The findings of Antibody screening 3 -cell panel and antibody identification 11- cell panel of the mother sample were similar as in case 1 suggestive of anti c alloantibody. Direct coomb's test of the baby was 
strongly positive (4+) and further DCT profile showed presence of IgG. Rh- kell antigen phenotyping revealed that mother was ' $c$ ' antigen negative, father was ' $c$ ' antigen positive and baby was ' $c$ ' antigen positive. (Figure 6) This further supported and confirmed our findings.

Thus, it was allo anti c antibody in the mother, which was causing moderate and severe HDFN in both the neonates. Elution studies of the baby sample could not be done in both the cases, as the sample was insufficient. Blood unit O Rh positive (R1R1), negative for c antigen was put up for AHG crossmatch and was issued for exchange transfusion in case 1 and for top up transfusion in case 2 with close follow up of the baby.

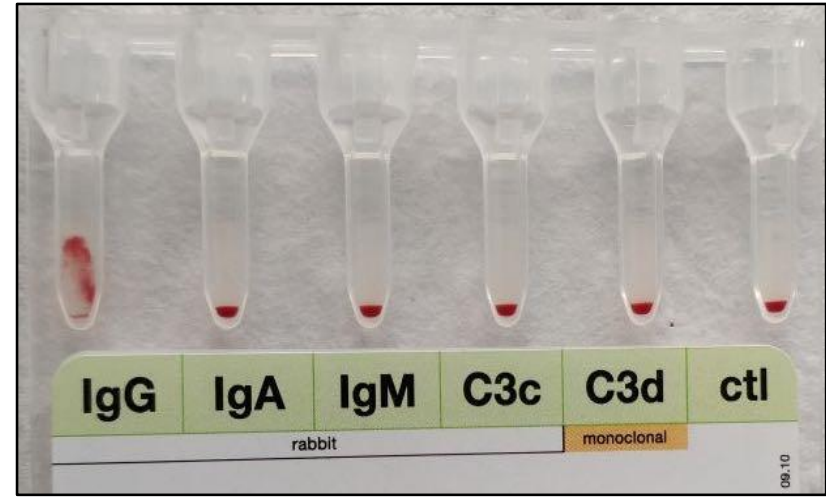

Figure 4: DCT profile showed presence of IgG by gel card method at $37^{\circ} \mathrm{C}$ (Case 1).

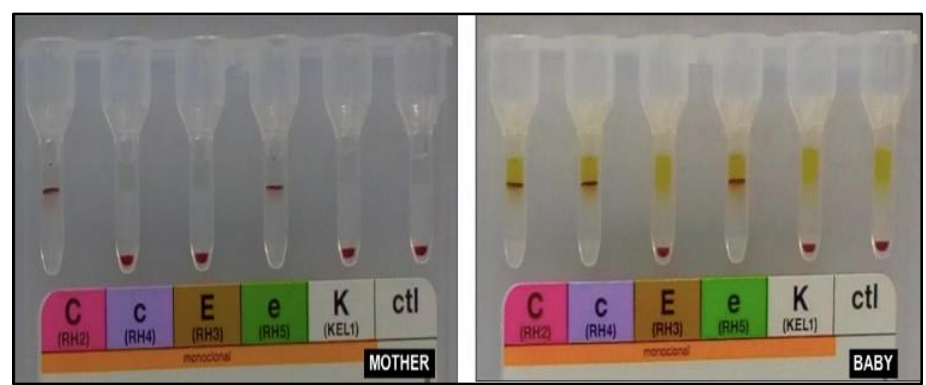

Figure 5: Rh kell antigen phenotyping in case 1 (mother was ' $c$ ' antigen negative, and baby was 'c' antigen positive).

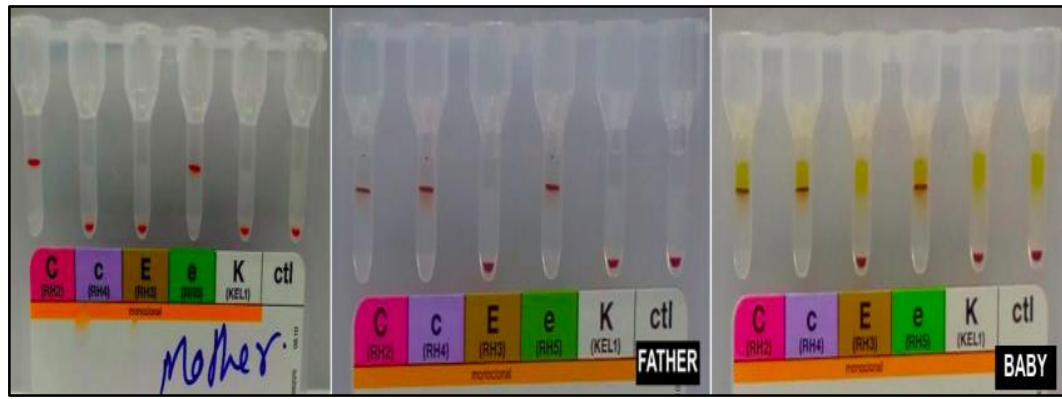

Figure 6: Rh kell antigen phenotyping in case 2 (mother was 'c' antigen negative; father was 'c' antigen positive and baby was ' $c$ ' antigen positive).

\section{DISCUSSION}

Antenatal services in India are fragmented and not uniform hence there is limited published data on alloimmunization rates among pregnant women in India.

Screening for alloantibodies in antenatal patients is being done primarily for $\mathrm{Rh} \mathrm{D}$ negative women or patients presenting with bad obstetric history due to which many clinically significant alloantibodies are missed in Rh D positive pregnant females causing HDFN in the baby.
This fact is clearly highlighted in both our cases as both the mothers were $\mathrm{Rh}$ positive and the neonates presented in our hospital emergency after delay of 4 or 5 days of life with markedly raised levels of serum bilirubin. Though HDFN is a preventable morbidity in neonates, but with such high levels of serum bilirubin the child had already developed bilirubin encephalopathy and the consequences caused by it are irreversible. The crucial time was wasted in antibody identification and crossmatch to search for a compatible blood unit for the baby. Moreover, antibody-screening techniques are not well developed in many centers. As a result the 
specificity of offending antibody could not be determined and they perform random cross match with $\mathrm{O} R \mathrm{Rh}$ negative blood unit presuming the offending antibody to be anti D. This leads to further delay in transfusion of compatible blood unit to the baby presenting with severe anemia as generally the $\mathrm{O}$ Rh negative blood units put up for crossmatch are incompatible with the baby sample. Many non-RhD alloantibodies are identified when neonate develops jaundice.

Table 1: Studies highlighting anti c iso-immunization and its outcome in pregnant females worldwide.

\begin{tabular}{|c|c|c|c|c|}
\hline Study & Year & $\begin{array}{l}\text { No. of pregnant } \\
\text { patients }\end{array}$ & Anti c Antibody prevalence & Pregnancy outcome \\
\hline Astrup $\mathrm{J}$ et $\mathrm{al}^{9}$ & 1977 & $\begin{array}{l}63 \text { antenatal patients } \\
\text { with anti c }\end{array}$ & $\begin{array}{l}63 \text {-pregnant women. In } 42 \text { cases- baby } \\
\text { was c antigen positive, c antigen } \\
\text { negative babies were excluded. }\end{array}$ & $\begin{array}{l}10 \text { neonates- unaffected } \\
30 \text { neonates- DAT +ve- mild } \\
\text { HDFN } \\
2 \text { neonates- Severe HDFN }\end{array}$ \\
\hline Hardy $\mathrm{J}$ et $\mathrm{al}^{10}$ & 1981 & $\begin{array}{l}3,80,790 \text { pregnant } \\
\text { females screened. In } \\
\text { 733antenatal cases- Rh } \\
\text { positive ICT + }\end{array}$ & $\begin{array}{l}\text { Grp 1: anti c, anti E, anti } \mathrm{c}+\mathrm{E} \text {, anti } \mathrm{C} \text {, } \\
\text { anti e= 571patients } \\
\text { Grp 2:non Rh antibodies }=136 \text { patients } \\
\text { Grp 3: } \mathrm{Rh}+\text { non } \mathrm{Rh} \mathrm{Ab}=26 \text { patients } \\
\text { (c+others }=13 \text { ) } \\
\text { Anti } \mathrm{c}=139 / 733(19 \%) \\
\text { Anti c+E-60 } / 733(8.2 \%) \\
\text { Anti c+ others systems-13/733(1.8\%) }\end{array}$ & $\begin{array}{l}\text { Infants of anti c Rh }+\mathrm{ve} \\
\text { mothers- } 166 \\
27 / 166(19.4 \%)-\text { needed } \\
\text { transfusion support } \\
3 / 166(2.2 \%) \text { - Death from } \\
\text { HDFN } \\
\text { Infants of anti c+E Rh +ve } \\
\text { mothers }=87 \\
12 / 87(17.4 \%) \text { transfusion } \\
\text { support } \\
2 / 87(3 \%)-\text { Death from HDFN } \\
\text { In grp } 3 \text { all infants needed } \\
\text { transfusion support. }\end{array}$ \\
\hline $\begin{array}{l}\text { Bowell PJ et } \\
\mathrm{al}^{11}\end{array}$ & 1986 & $\begin{array}{l}2,80,000 \\
\text { Pregnant women }\end{array}$ & $\begin{array}{l}\text { 177/280000(0.06\%)-anti c } \\
91-\text { only anti c } \\
67 \text { - antic+anti-E } \\
19 \text { - anti c+ one or more of the } \\
\text { following: anti-C }{ }^{\mathrm{w}} \text {, Lea, Leb, Jka,Jkb, s, } \\
\text { Kell, Kp }{ }^{\mathrm{a}}\end{array}$ & $\begin{array}{l}\text { 2- Severe HDFN } \\
\text { 11- DVET } \\
\text { 1-Mortality } \\
\text { Rest- unaffected }\end{array}$ \\
\hline $\begin{array}{l}\text { Koelewijn } \mathrm{J} \\
\text { et } \mathrm{al}^{12}\end{array}$ & 2000 & $\begin{array}{l}3,05,000 \text { antenatal } \\
\text { women } \\
1002 \text { antenatal women } \\
(\text { antibody screen }+ \text { ) }\end{array}$ & $\begin{array}{l}152 / 1002 \text { anti } \mathrm{c} \\
{[93-\text { only anti } \mathrm{c}} \\
47-\mathrm{c}+\mathrm{E} \\
12-\mathrm{c}+\text { other than anti-D, }-\mathrm{K}, \text { or }-\mathrm{E}]\end{array}$ & $\begin{array}{l}\text { 146/152- at risk for HDFN } \\
\text { (father +ve for the antigen) } \\
118 / 152=\text { infant c antigen +ve } \\
\text { Severe HDFN in } 12 \\
\text { cases/118(10.2\%) } \\
\text { [10- only antic } \\
1-\text { anti c +Ec+E } \\
1 \text { - anti c+ other non Rh] }\end{array}$ \\
\hline 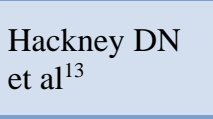 & 2004 & $\begin{array}{l}102 \text { pregnant women } \\
\text { with anti c } \\
55 \text { - complete details }\end{array}$ & 55 & $\begin{array}{l}46 / 55(84 \%)-\text { DAT +ve } \\
12 / 46(26 \%)-\text { Severe HDFN }\end{array}$ \\
\hline $\begin{array}{l}\text { Thakral B et } \\
\text { al }{ }^{14}\end{array}$ & 2007 & 01 & NA & Moderate HDFN \\
\hline 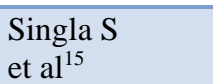 & 2010 & 01 & NA & $\begin{array}{l}\text { Severe HDFN } \\
\text { DVET }\end{array}$ \\
\hline $\begin{array}{l}\text { Murki } \\
\text { et } \mathrm{al}^{16}\end{array}$ & 2012 & 02 & NA & $\begin{array}{l}\text { Moderate HDFN } \\
\text { (1- DVET } \\
\text { (2- Phototherapy) }\end{array}$ \\
\hline $\begin{array}{l}\text { Sheeladevi } \\
\text { CS et } \mathrm{al}^{17}\end{array}$ & 2013 & 01 & NA & Severe HDFN fetal hydrops \\
\hline $\begin{array}{l}\text { Pandu Rao et } \\
\text { al }^{18}\end{array}$ & 2015 & 01 & NA & $\begin{array}{l}\text { Severe HDFN } \\
\text { DVET }\end{array}$ \\
\hline $\begin{array}{l}\text { Shyam } \\
\text { Sunder Mina } \\
\text { et al }{ }^{19}\end{array}$ & 2017 & 01 & NA & Moderate HDFN \\
\hline Present case & 2018 & $\begin{array}{l}2 \text { cases anti c antibody } \\
+\end{array}$ & NA & $\begin{array}{ll}\text { 1- } & \text { Severe HDFN } \\
\text { 2- } & \text { Moderate HDFN }\end{array}$ \\
\hline
\end{tabular}

(NA: Not Applicable) 
All antibodies to Rh-system antigens are considered capable of causing severe HDFN though anti-c is clinically the most important Rh antigen after anti-D and often causes severe HDFN, moderate HDFN can be caused by anti-Cw and anti-Cx whereas anti-C, -E, and -e rarely cause mild HDFN. ${ }^{2,5}$ Phenotypic frequency of " $\mathrm{c}$ " antigen and its potency is responsible for emerging anti $\mathrm{c}$ alloimmunization.

Alloimmunization in pregnant women varies from $0.4 \%$ to $2.7 \%$ worldwide. Very few studies are available from Indian subcontinent on prevalence and significance of alloantibodies in pregnancy. Alloimmunization rates in the $\mathrm{Rh}(\mathrm{D})$ antigen negative and $\mathrm{Rh}(\mathrm{D})$ antigen positive groups was $10.7 \%$ versus $0.12 \%$ respectively in a prospective study done in 3577 multigravida women by Pahuja et al in 2011 at our RBTC, out of which alloimmunization due to anti c antibody was seen in $1.96 \%$ cases. Lurie et al and Adenijii et al reported alloimmunization rates among $\mathrm{Rh}$ positive women $0.2 \%$ and $0.15 \%$ respectively. ${ }^{6-8}$

Majority of these studies are mainly from urban hospitals/ tertiary care centers. Hence exact magnitude of problem in rural India is not known. Globally with universal anti D Immunoprophylaxis non-D antibodies contribute to major chunk of alloimmunization in pregnancy. Also, there is paucity of literature on the studies emphasizing the role of Non $\mathrm{RhD}$ isoimmunization especially anti c antibody isoimmunization in $\mathrm{Rh}$ positive antenatal patients, monitoring of such pregnancies, degree of HDN in the fetus, its outcome and its management. Few studies in the past have highlighted anti c isoimmunization in $\mathrm{Rh}$ $\mathrm{D}$ positive pregnancies and reported the prevalence and outcome of pregnancies complicated by anti c alloimmunization (Table 1).

The first case of anti-c isoimmunization was reported in 1944, while the first case of HDN due to anti-c antibodies in $\mathrm{Rh}-\mathrm{D}$ positive mother in India was published in a retrospective diagnosis made in 2007. ${ }^{14,20}$ In fast growing economy of India it is very unfortunate that we have neonate morbidity and mortality due to HDFN. Though anti D Alloimmunization is prevalent, other non-D alloantibodies are manageable by repeated MCA-PSV and intrauterine transfusion with antigen negative blood unit. If anti $\mathrm{c}$ antibody is identified during antenatal screening of the pregnant female the follow up and management of these antenatal pregnant women with anti c alloimmunization is not currently defined, however, studies in the past have suggested that it is similar to that for individuals who harbor anti-D antibodies and suggested critical antibody titer of 1:32 while Bowell PJ et al suggested that pregnancies with titer $<16$ should be continued till term. ${ }^{11,21}$

\section{CONCLUSION}

In majority of transfusion and antenatal care centers in India and other developing countries; routine antenatal antibody screening is done only for $\mathrm{Rh}-\mathrm{D}$ negative mothers to screen for anti-D antibodies. Universal screening of all antenatal women, including $\mathrm{D}$ antigen positive pregnant ones is highly debated and controversial. Antenatal antibody screening should be done in all $\mathrm{Rh}$-positive pregnant women.

The screening guidelines for Rh-D positive females are not clearly defined due to unawareness regarding the potential of these antibodies in causing HDN and perinatal mortality apart from the its cost factor. This results in delay in the diagnosis of HDN due to Non anti$\mathrm{D}$ isoimmunization in the fetus resulting in HDFN.

Severe HDFN caused by antibodies other than anti-D can be treated with intrauterine transfusions (IUTs) during pregnancy and with exchange transfusions after birth.

A close follow-up throughout pregnancy is essential if irregular antibodies are present so that antigen negative compatible blood can be provided in a timely manner for exchange transfusions to reduce the incidence of preventable perinatal mortality and morbidity .The management of anti-c isoimmunization or isoimmunization with any other irregular red cell antibody is similar to the management of anti- D isoimmunised pregnancy with a specification that blood unit used for fetal and/or neonatal transfusion should be negative for that antigen.

\section{Funding: No funding sources \\ Conflict of interest: None declared \\ Ethical approval: Not Required}

\section{REFERENCES}

1. Harmening D. Modern blood banking \& transfusion practices. $6^{\text {th }}$ ed. Philadelphia: F.A. Davis; Chapter 19 Hemolytic Disease of the Fetus and Newborn (HDFN); 2012:672.

2. Levine P, Burnham L, Katzin EM, Vogel P. The role of iso-immunization in the pathogenesis of erythroblastosis fetalis. JAMA 1941;113:126-7.

3. Poole J, Daniels G. Blood group antibodies and their significance in transfusion medicine. Transfus Med Rev. 2007 Jan;21(1):58-71.

4. Basu S, Kaur R, Kaur G. Hemolytic disease of the fetus and newborn: Current trends and perspectives. Asian J Transfus Sci. 2011 Jan;5(1):3-7.

5. Daniels G, Bromilow I. Essential guide to blood groups. 3rd ed. West Sussex: Wiley; Chapter 4, The Rh blood group system; 2016:35-48.

6. Pahuja S, Gupta SK, Pujani M, Jain M. The prevalence of irregular erythrocyte antibodies among antenatal women in Delhi. Blood Transfus. 2011 Oct;9(4):388-93.

7. Lurie S, Eliezer E, Piper I, Woliovitch I. Is antibody screening in $\mathrm{Rh}(\mathrm{D})$ - positive pregnant women necessary? J Mater Fetal Neo-natal Med. 2003;14:404-6. 
8. Adeniji AA, Fullar I, Dale T, Lindow SW. Should we continue screening Rhesus D positive women for the development of atypical antibodies in late pregnancy? J Matern Fetal Neonatal Med. 2007;20:59-61.

9. Astrup J, Kornstad L. Presence of anti-c in the serum of 42 women giving birth to $\mathrm{c}$ positive babies: serological and clinical findings. Acta Obstet Gynecol Scand. 1977;56(3):185-8.

10. Hardy J, Napier JA. Red cell antibodies detected in antenatal tests on rhesus positive women in South and Mid Wales, 1948-1978. Br J Obstet Gynaecol. 1981 Feb;88(2):91-100.

11. Bowell PJ, Brown SE, Dike AE, Inskip MJ. The significance of anti-c alloimunization in pregnancy. Br J Obstet Gynecol. 1986;93:1044-8.

12. Koelewijn JM, Vrijkotte TG, Van der Schoot CE, Bonsel GJ, De Haas M. Effect of screening for red cell antibodies, other than anti-D, to detect hemolytic disease of the fetus and newborn: a population study in the Netherlands. Transfusion. 2008 May;48(5):941-52.

13. Hackney DN, Knudtson EJ, Rossi KQ, Krugh D, O'Shaughnessy RW. Management Of Pregnancies Complicated By Anti-C Isoimmunization. Obstet Gynecol. 2004;103(1):24-30.

14. Thakral B, Agrawal SK, Dhawan HK, Saluja K, Dutta S, Marwaha N. First report from India of haemolytic disease of newborn by anti-c and anti-E in $\mathrm{Rh}$ (D) positive mothers. Hematology. 2007;12:377-80.

15. Singla S, Kumar S, Roy KK, Sharma JB, Kachhawa G. Severe hydrops in the infant of a Rhesus D- positive mother due to anti-c antibodies diagnosed antenatally: a case report. J Med Case Rep. 2010 Feb 18;4:57.

16. Murki S, Kandraju H, Devi SA. Hemolytic disease of the newborn- anti c antibody induced hemolysis. Indian J Pediatr. 2012 Feb;79(2):265-6.

17. Sheeladevi CS, Suchitha S, Manjunath GV, Murthy S. Hemolytic Disease of the Newborn Due to Anti-c Isoimmunization: A Case Report. Indian J Hematol Blood Transfus. 2013 Sep;29(3):155-7.

18. Rao SPR, Vujhini SK. Alloimmunisation in $\mathrm{Rh}$ "c" negative mother causing severe fetal hemolysis. Int J Contemp Pediatr. 2015;2:454-5.

19. Mina SS, Bhardwaj R, Gupta S. Hemolytic disease of newborn: Can think beyond $\mathrm{Rh}$ (D) and $\mathrm{ABO}$ incompatibilities. J Clin Neonatol 2017;6:37-9.

20. McCall AJ, Race RR, Taylor GL. Rhesus antibody in Rh-positive mother causing hemolytic disease of newborn. Lancet. 1944;i:214-5.

21. Hackney DN, Knudtson EJ, Rossi KQ, Krugh D, O'Shaughnessy RW. Management of pregnancies complicated by anti-c isoimmunization. Obstet Gynecol. 2004 Jan;103(1):24-30.

Cite this article as: Sharma G, Pahuja S, Singh D, Ramvilash, Manisha. Non RhD isoimmunization causing severe hemolytic disease of fetus and newborn in $\mathrm{Rh}$ positive pregnancies: report of 2 cases with review of literature. Int J Contemp Pediatr 2020;7:955-60. 